\title{
Polymerization of DL-Lactide induced by Protonated Montmorillonite clay as a solid catalyst: Mechanism study
}

\author{
Elkebir Aslya ${ }^{a}$, Amine Harrane ${ }^{a *}$, Mohamed Belbachir ${ }^{a}$ \\ ${ }^{a}$ Laboratoire de Chimie des Polymères, Département de Chimie, Faculté des Sciences exactes et \\ appliquées, Université d'Oran1 Ahmed Benbella, BP 1524 El M'naouer, 31000 Oran, Algeria
}

Received: June 1, 2015 ; Revised: October 27, 2015; Accepted: November 20, 2015

\begin{abstract}
Maghnite- $\mathrm{H}^{+}$is Algerian montmorillonite sheet alumino-silicate clay, exchanged with protons $\left(\mathrm{H}^{+}\right)$. This solid non-toxic catalyst was successfully used as cationic catalyst for the polymerization of D,L-Lactid at $100^{\circ} \mathrm{C}$. Interactions between Maghnite- $\mathrm{H}^{+}$platelets and the monomer (D,L-Lactide) were studied by solid state ${ }^{1} \mathrm{H},{ }^{27} \mathrm{Al}$ and ${ }^{29} \mathrm{Si}$ NMR spectroscopy. The results show that, the mechanism of the reaction involves both Brønsted and Lewis acid sites on Maghnite surface.
\end{abstract}

Keywords: D, L-Lactide, poly (D,L-Lactide), PLA, Solid state NMR, , Montmorillonite, Solid Catalyst.

\section{Introduction}

Poly(D,L-Lactide), (PLA) is a biodegradable and biocompatible polymer. It is usually used in biomedical applications such as controlled drug release matrix, scaffolds for tissue engineering, sutures and constructing medical devices ${ }^{1-3}$. Conventionally PLA is synthesized by the polymerization of $\mathrm{D}, \mathrm{L}-$ Lactide. This reaction is mostly induced by the use of metallic or organometallic catalysts, such as, organo-stannous derivatives ${ }^{3,4}$. These homogenous catalysts are efficient, but have some disadvantages: they are corrosives which makes them difficult to handle and it is so difficult to remove them from the resulted products. In recent years, the growth of the environmental requirements, have resulted in a demand for alternative catalytic processes. In this regard, many studies have been carried out on the development of new solid acids, such as "Keggin-type Heteropolycompounds"5-8 or acidic clay catalysts ${ }^{9-11}$, to replace corrosives homogeneous acids and to resolve the problems related to the purification of the resulted polymers. Therefore, the replacement of classic homogeneous catalysts (such as Lewis acid) by heterogeneous system can offer many advantages: besides of the respect of green chemistry basis, heterogeneous catalysts give easier separation, possible higher product yields and mild reaction conditions ${ }^{8}$.

In our previous works, we have already reported about polymerization reactions catalyzed by Maghnite- $\mathrm{H}^{+}$, a proton exchanged montmorillonite clay. This new non-toxic available eco-catalyst exhibited higher efficiency via the cationic polymerization of vinylic and hetero-cyclic monomers ${ }^{10-18}$. The aim of this study is to elucidate the interactions between the monomer (D, L-Lactide) and the inorganic platelets of Maghnite occurring upon the reaction of polymerization. For this reason we have used solid state NMR spectroscopy to elucidate the action of Maghnite- $\mathrm{H}^{+}$such as Brønsted and Lewis acid catalyst upon the polymerization reaction.

*e-mail: harrane.amine@univ-oran-.dz
Techniques such as ${ }^{1} \mathrm{H}$ NMR, GPC and viscosimetry were also used to confirm the structure of the resulted polymer.

\section{Experimental Procedure}

\subsection{Materials}

Raw-Maghnite: Algerian Montmorillonite clay, was procured from "Algerian Society of Bentonite". D,L-Lactide was purchased from Aldrich Co, it was purified by crystallization from dried ethylacetate and dried under reduced pressure before use. Methanol was dried over magnesium sulphate $\mathrm{MgSO}_{4}$ and distilled. Ethylacetate was used as received. Dichloromethane was dried over $\mathrm{MgSO}_{4}$ and distilled on the day of experiment.

\subsection{Preparation of the Maghnite- $H^{+}$}

Raw-Maghnite (20g) was crushed for 20 min using a Prolabo ceramic balls grinder. It was then dried by baking at $105^{\circ} \mathrm{C}$ for 2 hours. The Maghnite was then weighted and placed in an Erlenmeyer flask together with $500 \mathrm{ml}$ of distilled water. The Maghnite/water mixture was stirred using a magnetic stirrer and combined with $500 \mathrm{ml}$ sulphuric acid solution $(0,5 \mathrm{M})$. Until saturation was achieved over 2 days at room temperature, the mineral was washed with distilled water until became sulphate free and then dried at $105^{\circ} \mathrm{C}$.

\subsection{Polymerization and kinetics procedure}

PLA was prepared by a ring opening bulk polymerisation of D,L-Lactide catalysed by Maghnite- $\mathrm{H}^{+}$. The reaction was carried out at $100^{\circ} \mathrm{C}$. Each mixture was prepared with $1.44 \mathrm{~g}$ $(10 \mathrm{mmol})$ of D,L-Lactide and an amount of Maghnite- $\mathrm{H}^{+}$ and introduced in a sealed tube. The mixture of (Lactide) and Maghnite- $\mathrm{H}^{+}$was stirred under dry nitrogen with a magnetic stirrer. After a required period of time, the reaction of polymerization was terminated by adding Methanol and then the mixture was cooled. For kinetics measurements, the 
resulting polymer was extracted with adequate amount of Dichloromethane, precipitated in Methanol, filtered, washed for several times and dried at $50^{\circ} \mathrm{C}$ under reduced pressure. The yield of the reaction was determined gravimetrically.

\subsection{Polymer characterizations}

Spectroscopic ${ }^{1} \mathrm{H}$ NMR measurements were recorded, under ambient temperature and using DMSO-d6 as solvent, on an "AM 300 FT Bruker spectrometer. Tetramethylsilane was used as internal standard. GPC, Gel-permeation chromatography, was performed on "Spectra-Physics" chromatograph, equipped with four columns of Ultrastyragel $\left(10^{3}, 10^{4}, 10^{5}\right.$ and $\left.10^{6} \mathrm{~A}^{\circ}\right)$. The used solvent is THF and the calibration of the apparatus was carried out with polystyrene of known molecular weights. Measurements of "Average viscosimetric Molecular weight" were carried out with an "Ubbelohde capillary viscosimeter" (Semantec ViscologicTI1, V 3-1). Intrinsic viscosity, [n] (mL/ g), was measured in THF at $25^{\circ} \mathrm{C}$. The relationship between the viscosity - average molecular weight $\mathrm{Mv}$ and the intrinsic viscosity (Staudinger index) is given for PLA (in $\mathrm{CHCl}_{3}$, at $25^{\circ} \mathrm{C}$ ), by the Mark-Houwink equation ${ }^{19}$ :

$[\eta]=2,21 \cdot 10^{-4} \mathrm{Mv}^{0,77}$.

\subsection{Solid state NMR Characterization}

Solid state ${ }^{27} \mathrm{Al}$, and ${ }^{29} \mathrm{Si}$ NMR spectra were recorded with a Bruker spectrometer (Avance 500) using Tetramethylsilane for ${ }^{1} \mathrm{H}$ and ${ }^{29} \mathrm{Si}$, and $\mathrm{Al}\left(\mathrm{NO}_{3}\right)_{3} \times 6 \mathrm{H}_{2} \mathrm{O}$ in water for ${ }^{27} \mathrm{Al}$ as the 0 ppm external references for the chemical shifts. MAS experiments were performed, with a probe having $2.5 \mathrm{~mm}$ $\mathrm{ZrO}_{2}$ rotors, at a spinning rate of $30 \mathrm{KHz}$ for ${ }^{1} \mathrm{H}$ and ${ }^{27} \mathrm{Al}$ and $10 \mathrm{kHz}$ for ${ }^{29} \mathrm{Si}$.

\subsection{XRD and XRF Characterization}

X-Ray Diffraction (XRD) profiles for pressed powder samples were recorded on a Philips PW 1710 diffractometer using $\mathrm{Cu}-\mathrm{K} \alpha$ radiation $(\lambda=1.5418 \AA)$. Samples for $\mathrm{X}$-Ray Fluorescence (XRF) analysis were prepared using the $\mathrm{LiB}_{4} \mathrm{O}_{7}$ fusion method. The resulting beads were analysed on a Philips PW 2400XRF spectrometer.

\section{Results and Discussion}

\subsection{Maghnite Structure.}

The composition and the structure of Maghnite- $\mathrm{H}^{+}$were reported in a previous works ${ }^{10,18}$, in which we have demonstrated that Maghnite is a Montmorillonite clay with basic repeating unit: $\left[\mathrm{Si}_{4} \mathrm{O}_{10} \mathrm{Al}^{3+}(2-x) \mathrm{Mg}^{2+} x(\mathrm{OH})_{2}\right]$ (Figure 1). Table 1 shows the chemical composition of Maghnite- $\mathrm{H}^{+}$obtained by XRF analysis. The results show the alumino-silicate nature of the material.
XRD measurements of Maghnite- $\mathrm{H}^{+}$(Figure 2) show a broad peak of $\mathrm{H}^{+}$-MMT centered on a value of $15.8 \mathrm{~A}^{\circ}$, indicating that the layer distance in Maghnite- $\mathrm{H}^{+}$is $15.8 \mathrm{~A}^{\circ}$. Such as they were attributed in a previous work ${ }^{10}$, the other peaks are related to the structure of Montmorillonite aluminum-oxygen octahedron and silicon-oxygen tetrahedron ${ }^{10,20}$.

The comparison between the diffractograms of Maghnite (figure 2(a) ) and Maghnite/Polymer mixture after the reaction (figure 2 (b) ), shows that there are no significant changes on the cristallogaphic structure of Maghnite- $\mathrm{H}^{+}$after the reaction. We can then conclude that the polymerization occurs only on the surface of Maghnite- $\mathrm{H}^{+}$.

\subsection{Polymerization of DL-Lactide by Maghnite- $\mathrm{H}^{+}$}

The bulk cationic ring opening polymerization of DL-Lactide was catalyzed by Maghnite- $\mathrm{H}^{+}$at $100^{\circ} \mathrm{C}$ (scheme1). The results are reported in Table 2 . The structure of the prepared PLA was confirmed by ${ }^{1} \mathrm{H}$ NMR (figure 3$)^{11}$. As shown in table 2, increasing of Maghnite- $\mathrm{H}^{+} /$Monomer weight ratio causes increasing in the rate of the polymerization (expressed by the yield) and decreasing in the average viscosimetric molecular weight $(\mathrm{Mv})$ of the resulted polymer. These results show clearly, the effect of Maghnite- $\mathrm{H}^{+}$as a cationic catalyst for D,L-Lactide polymerization. Similar results are obtained in our previous work in the polymerization of Isobutylene by Maghnite- $\mathrm{H}^{+}$which polymerizes only by cationic process ${ }^{10}$.

\section{3. ${ }^{~} H$ MAS NMR Spectroscopy}

The ${ }^{1} \mathrm{H}$ MAS NMR spectrums of Maghnite- $\mathrm{H}^{+}$ (figure 4) show two broad peaks at chemical shift values at 2.2 and $6.9 \mathrm{ppm}$. The peak at $2.2 \mathrm{ppm}$ is attributed to protons of hydroxyl groups in the octahedral sheet of Maghnite; this signal is compatible with the di-octahedral nature of the clay ${ }^{21}$. The peak at 6.9 ppm can be assigned to Brønsted acid sites on the surface of catalyst. This signal is in good agreement with those assigned to solid acids ${ }^{22-23}$.

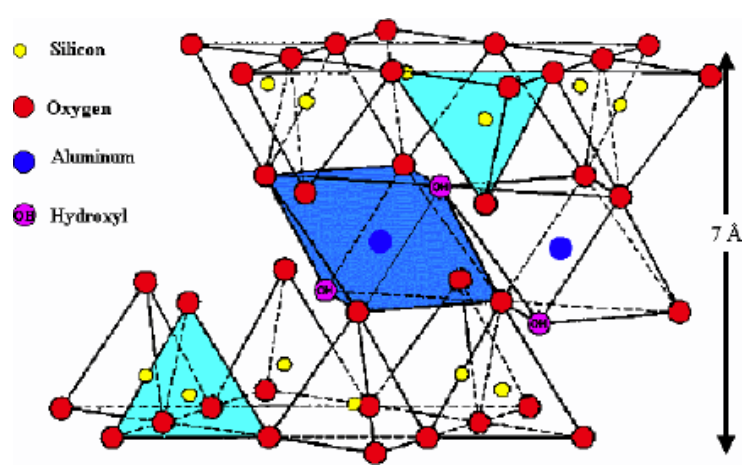

Figure 1. Cristallographic structure of Maghnite (Basic repeating unit is $\left.\left[\mathrm{Si}_{4} \mathrm{O}_{10} \mathrm{Al}^{3+}(2-\mathrm{x}) \mathrm{Mg}^{2+} \mathrm{x}(\mathrm{OH})_{2}\right]\right)$

Table 1. Composition (in \%) of Maghnite by X-Ray Fluorescence (XRF) analysis.

\begin{tabular}{|c|c|c|c|c|c|c|c|c|c|c|c|}
\hline Sample & $\mathrm{SiO}_{2}$ & $\mathrm{Al}_{2} \mathrm{O}_{3}$ & $\mathrm{Fe}_{2} \mathrm{O}_{3}$ & $\mathrm{FeO}$ & $\mathrm{CaO}$ & MgO & $\mathrm{Na}_{2} \mathrm{O}$ & $\mathrm{K}_{2} \mathrm{O}$ & $\mathrm{TiO}_{2}$ & $\mathrm{SO}_{3}$ & $\begin{array}{c}\text { Water loss } \\
\text { at } 110^{\circ} \mathrm{C}\end{array}$ \\
\hline Maghnite-H ${ }^{+}$ & 71.70 & 14.03 & 0.71 & 00 & 0.28 & 0.80 & 0.21 & 0.77 & 0.15 & 0.34 & 11.05 \\
\hline
\end{tabular}




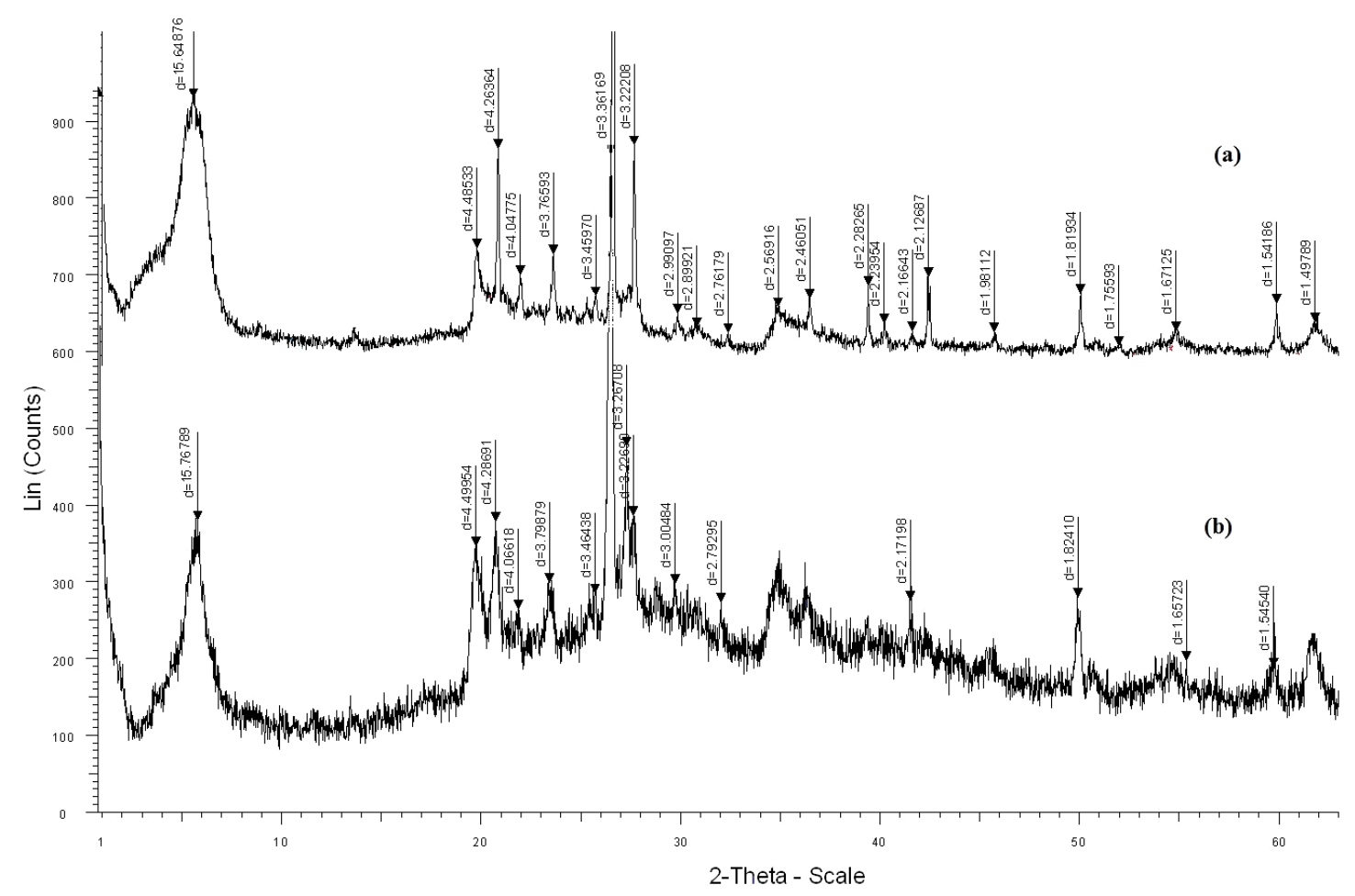

Figure 2. X-ray powder Diffractions of Maghnite- $\mathrm{H}^{+}$(a) and Maghnite- $\mathrm{H}^{+} /$Polymer mixture after the reaction (b) (recorded on a Philips PW 1710 diffractometer using $\mathrm{Cu}-\mathrm{K} \alpha$ radiation $\left(\lambda=1.5418 \mathrm{~A}^{\circ}\right), \mathrm{d}$ is reported in $\left.\mathrm{A}^{\circ}\right)$
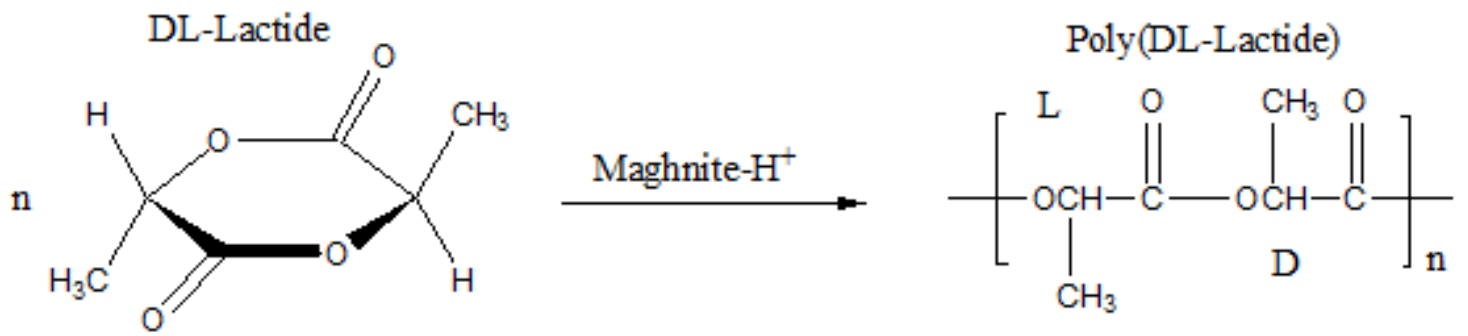

Scheme 1. Polymerization of D,L- Lactide by Maghnite- $\mathrm{H}^{+}$

In a previous work ${ }^{15}$, we have demonstrated that $9,6 \mathrm{ppm}$ signal correspond, respectively, to $\mathrm{AlOH}$ and $\mathrm{SiOH}$ groups in the vicinity of $\mathrm{Al}$ atoms. Accordingly, Brønsted acidic protons in $\mathrm{Si}(\mathrm{OH}) \mathrm{Al}$ units should come from some isomorphic $\mathrm{Al}$ substitution in the tetrahedral sheets.

\section{4. ${ }^{27}$ Al MAS NMR Spectroscopy}

${ }^{27} \mathrm{Al}$ MAS NMR is a useful method to distinguish between tetrahedral $\mathrm{AlO}_{4}$ and octahedral $\mathrm{AlO}_{6}$ units in the material ${ }^{24-25}$. Figure 5 shows the ${ }^{27} \mathrm{Al}$ MAS spectra of Maghnite- $\mathrm{H}^{+}$and Maghnite- $\mathrm{H}^{+} /$Polymer mixture after the reaction of polymerization respectively. The chemical shifts are summarized in table 3 . The spectra provide information about the local environment of the aluminum sites in Maghnite, two small bands of two tetra-coordinated $\mathrm{AlO}_{4}\left(\mathrm{Al}_{\mathrm{TD} 1}\right.$ and $\left.\mathrm{AL}_{\mathrm{Td} 2}\right)$ at $58-60 \mathrm{ppm}$ and $68-71 \mathrm{ppm}$, and another signal at 3-4 ppm attributed to octahedral $\mathrm{AlO}_{6}\left(\mathrm{Al}_{\mathrm{Oh}}\right)^{25}$. $\mathrm{AlO}_{4}$ sites in the maghnite structure are the consequence of isomorphic ions substitution within the silicate layers ${ }^{10,15-17}$.

Meanwhile, the ${ }^{27} \mathrm{Al} \mathrm{NMR}$ spectra of Maghnite- $\mathrm{H}^{+}$and of Maghnite- $\mathrm{H}^{+} /$Polymer mixture after the reaction were closely identical, two very significant differences were observed in the ${ }^{27} \mathrm{Al}$ NMR spectra. The (D,L-Lactide) polymerization induced by Maghnite- $\mathrm{H}^{+}$leads to an increase in the proportion of $\mathrm{Al}$ in the hexa-coordinated site and a decrease in the proportion of $\mathrm{Al}$ in only one tetra-coordinated site $\left(\mathrm{Al}_{\mathrm{Tdl}}\right)$ at $\sim 70 \mathrm{ppm}$. This result suggests that the signal at $\sim 60 \mathrm{ppm}$ corresponds to non-reactive sites of the layered alumino-silicate, while 


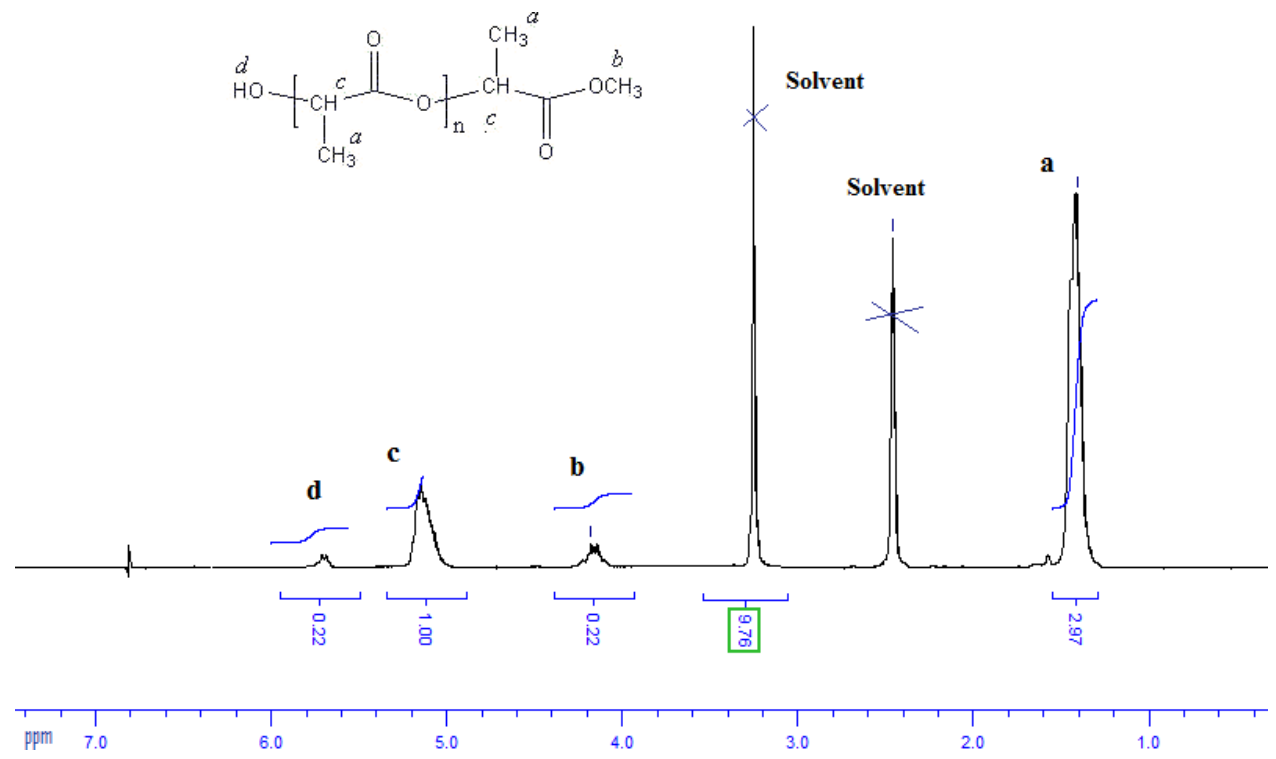

Figure 3. ${ }^{1} \mathrm{H}$ NMR spectrum of poly (D,L-Lactide) in DMSO-d6

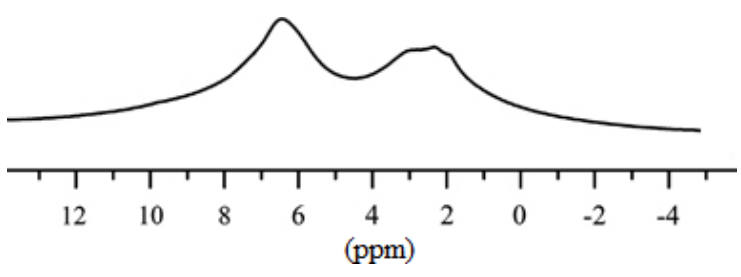

Figure 4. ${ }^{1} \mathrm{H}$ MAS spectrum of Maghnite- $\mathrm{H}^{+}$(recorded with a $\pi / 4$ pulse of $3.4 \mu \mathrm{s}, 80$ scans, a recycle delay of $4 \mathrm{~s}$ and spinning frequencies of $30 \mathrm{kHz}$.

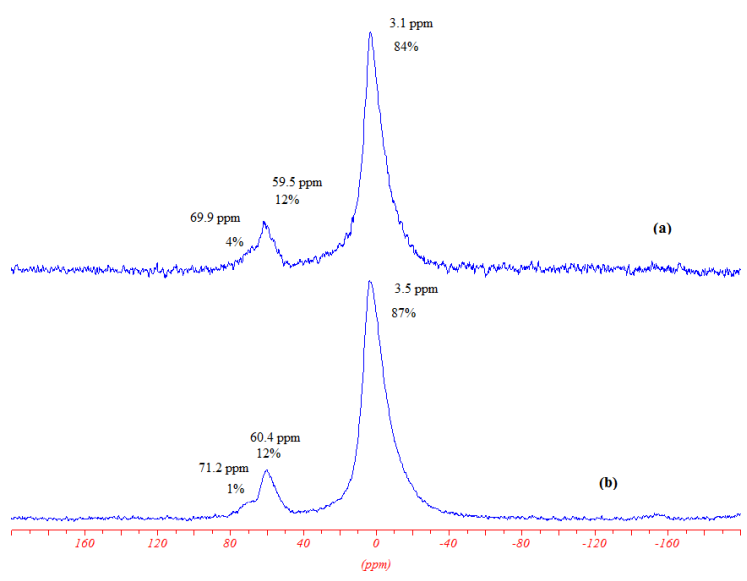

Figure 5. ${ }^{27} \mathrm{Al}$ MAS spectra of the different samples, (a) Maghnite- $\mathrm{H}^{+}$; (b) Maghnite- $\mathrm{H}^{+} /$Polymer mixture after the reaction, spinning frequency: $30 \mathrm{kHz}$.

the signal at $\sim 70 \mathrm{ppm}$ is rather due to different reactive sites $^{25-26}$. We can then conclude that polymerization reaction occurs specifically on the active specific tetra-coordinated Al sites, which transforms it into hexa-coordinated Al sites. This result shows that $\mathrm{ALO}_{4}$ tetrahedral aluminum on the surface of Maghnite contributes to the polymerization reaction of Lactide as Lewis acid catalyst.
Table 2. Kinetics of D,L-lactide polymerisation catalysed by Maghnite- $\mathrm{H}^{+}\left(\mathrm{T}=100^{\circ} \mathrm{C}\right)$

\begin{tabular}{ccccc}
\hline $\begin{array}{c}\text { Maghnite/ } \\
\text { Lactide }_{\mathbf{w}}^{\mathbf{\%}}\end{array}$ & Time(h) & $\begin{array}{c}\text { Yields } \\
\mathbf{\%}\end{array}$ & $\begin{array}{c}\text { Mv } \mathbf{x} \\
\mathbf{1 0}^{-3}\end{array}$ & Mw/Mn \\
\hline $\mathbf{5}$ & 3 & 03.5 & 2.3 & 1.10 \\
$\mathbf{5}$ & 4 & 15 & 4 & 1.16 \\
$\mathbf{5}$ & 5 & 18 & 6.3 & 1.21 \\
$\mathbf{5}$ & 7 & 37 & 8.4 & 1.26 \\
$\mathbf{5}$ & 9 & 41 & 9.5 & 2.10 \\
$\mathbf{1 0}$ & 3 & 05 & 2.8 & 1.11 \\
$\mathbf{1 0}$ & 4 & 21 & 3.5 & 1.23 \\
$\mathbf{1 0}$ & 5 & 25 & 4.5 & 1.19 \\
$\mathbf{1 0}$ & 7 & 52 & 5.1 & 1.29 \\
$\mathbf{1 0}$ & 9 & 56 & 6.3 & 2.36 \\
$\mathbf{1 5}$ & 3 & 7 & 1.1 & 1.10 \\
$\mathbf{1 5}$ & 4 & 35 & 2 & 1.28 \\
$\mathbf{1 5}$ & 5 & 37 & 2.2 & 1.37 \\
$\mathbf{1 5}$ & 7 & 57 & 2.5 & 1.36 \\
$\mathbf{1 5}$ & 9 & 64 & 3.1 & 2.20 \\
\hline
\end{tabular}

\section{5. ${ }^{29} \mathrm{Si}$ MAS NMR Spectroscopy}

${ }^{29} \mathrm{Si}$ MAS NMR spectra provide supporting evidence for no change occurring on silicate sites of the Maghnite- $\mathrm{H}^{+}$. ${ }^{29} \mathrm{Si}$ MAS NMR [Figure 6(a)] of Maghnite- $\mathrm{H}^{+}$exhibits a strong signal at $-94.5 \mathrm{ppm}$ that corresponds to the $\mathrm{Q} 4(1 \mathrm{Al})^{27}$.

\subsection{Mechanism of polymerization}

According to theoretical studies on acid catalytic properties of montmorillonite structure ${ }^{28-32}$, the Brønsted acidity alone seems therefore not enough to explain the observed high acid-catalytic activity of the material. Lewis acidity is then of importance for such a catalytic reaction. Indeed, it has been concluded that the reaction occurs at places having both the hydroxyl group and an accessible 
Table 3. ${ }^{27} \mathrm{Al}$ NMR Chemical Shifts and Signal Area (\%) in Maghnite- $\mathrm{H}^{+}$and Maghnite/Polymer mixture after reaction

\begin{tabular}{|c|c|c|c|c|c|c|}
\hline \multirow{2}{*}{ Sample } & \multicolumn{2}{|c|}{$\left(\mathrm{Al}_{\mathrm{Oh}}\right)$} & \multicolumn{2}{|c|}{$\left(\mathrm{Al}_{\mathrm{Td} 1}\right)$} & \multicolumn{2}{|c|}{$\left(\mathrm{Al}_{\mathrm{Td} 2}\right)$} \\
\hline & $\delta(p p m)$ & Area $(\%)^{a}$ & $\delta(\mathrm{ppm})$ & Area $(\%)^{a}$ & $\delta(\mathrm{ppm})$ & Area $(\%)^{a}$ \\
\hline Maghnite- $\mathrm{H}^{+}$ & 3.1 & 84 & 59.5 & 12 & 69.9 & 4 \\
\hline $\begin{array}{l}\text { Maghnite/Polymer mixture after } \\
\text { reaction }\end{array}$ & 3.5 & 87 & 60.4 & 12 & 71.2 & 1 \\
\hline
\end{tabular}

${ }^{a}$ By spectral decomposition using dmfit software program.

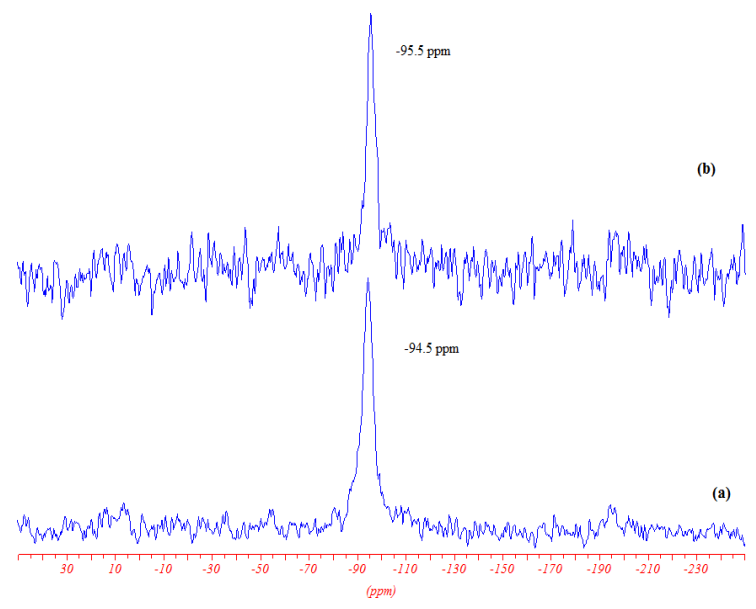

Figure 6. ${ }^{29} \mathrm{Si}$ MAS spectra of the different samples, a) Maghnite- $\mathrm{H}^{+}$; (bMaghnite- $\mathrm{H}^{+} /$Polymer mixture after the reaction, spinning frequency : $10 \mathrm{kHz}$.

aluminum site acting concertedly as co-localized strong Brønsted and Lewis acidic sites ${ }^{31,32}$.

Our present study is consistent with a mechanism involving the initiation of the cationic polymerization of (D,L-Lactide) at the surface of the clay, by the monomer addition on an aluminum Lewis acidic site and assisted by a subsequent neighbor Brønsted acidic site. Thus, the activation of the monomer occurs on Al-O tetra-coordinated sites of the clay as indicated by ${ }^{27} \mathrm{Al} \mathrm{NMR}$. The driving force of cationic polymerization reaction is therefore the ability of these active sites to direct the supported propagation process.

Scheme 2 shows the proposed schematic mechanism of acid catalyzed polymerization of (D,L-Lactide) onto clay surface.

\section{References}

1. Sodergard A and Stolt M. Properties of lactic acid based polymers and their correlation with composition. Progress in Polymer Science. 2002; 27(6):1123-1163. http://dx.doi.org/10.1016/ S0079-6700(02)00012-6.

2. Okada M. Chemical syntheses of biodegradable polymers. Progress in Polymer Science. 2002; 27(1):87-133. http://dx.doi. org/10.1016/S0079-6700(01)00039-9.

3. Nishida H, Yamashita M, Endo T and Tokiwa Y. Equilibrium polymerization behavior of 1,4-dioxan-2-one in bulk.

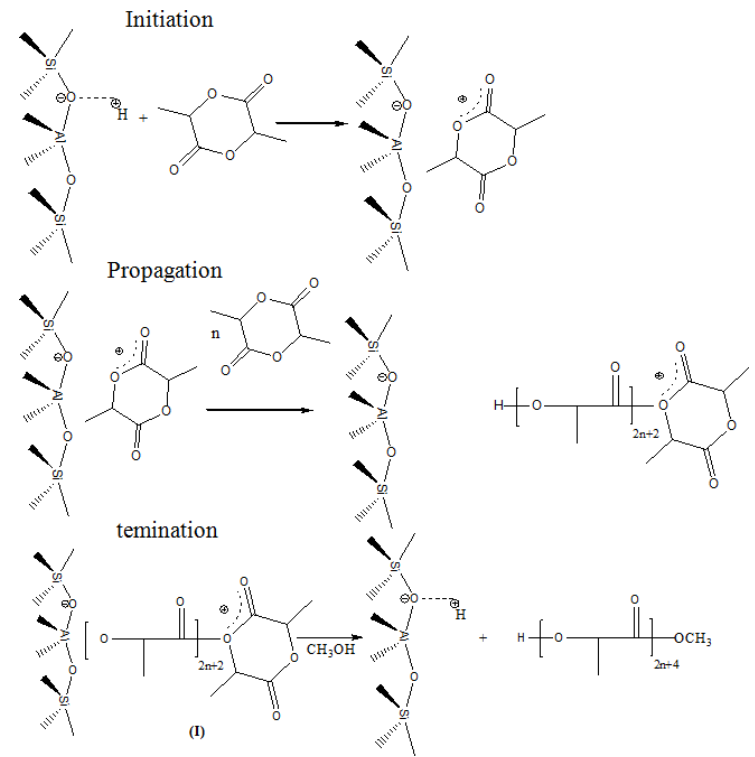

Scheme 2. Mechanism of D,L-Lactide polymerization catalyzed by Maghnite- $\mathrm{H}^{+}$

\section{Conclusions}

The present work shows that D,L-Lactide polymerization can be induced in heterogeneous phase by proton exchanged montmorillonite clay called Maghnite- $\mathrm{H}^{+}$. Poly (D,L-Lactide) was produced by an available non-toxic cationic catalyst and by an easy-to-handle procedure in one batch process. This study clearly demonstrates the effectiveness of Brønsted/Lewis acidic sites on the clay interface to induce D,L-lactide polymerization. Solid NMR measurements demonstrate that, the polymerization is therefore consistent with a concerted Brønsted/Lewis acid catalyzed mechanism. This chemistry may be a potential direct method to produce poly(D,L-Lactide)/ montmorillonite nanocomposites.

Macromolecules. 2000; 33(19):6982-6986. http://dx.doi. org/10.1021/ma000457t.

4. Van de Velde K and Kiekens P. Biopolymers: overview of several properties and consequences on their applications. Polymer Testing. 2002; 21(4):433-442.

5. Kricheldorf HR, Saunders IK and Stricker A. Polylactones, SnOct2-Initiated polymerizations of lactide : A mechanistic study. Macromolecules. 2000; 33:702-709.

6. Kaplan H. One step process of acid activating mineral clays and alkylating phenolic compounds with an alkene hydrocarbon. US Patent 3287422. 1966. 
7. Kunioka M, Wang Y and Onozawa S. Poly(lactic acid) polymerized by aluminum triflate. Macromolecular Symposia. 2005; 224(1):167-180. http://dx.doi.org/10.1002/masy.200550615.

8. Yingmin Y, Ruying L and Qingsong L. Alkylation of thiophenic compounds with 1-hexene over sulfonated solid acid catalysts. Progress in Reaction Kinetics and Mechanism. 2013; 4:425430.

9. Nascimento AR, Alves JA, Melo MA, Melo DM, Souza MJ and Pedrosa AM. Effect of the acid treatment of montmorillonite clay in the oleic acid esterification reaction. Materials Research. 2015; 18(2):283-287. http://dx.doi.org/10.1590/1516-1439.293014.

10. Harrane A, Meghabar R and Belbachir M. A Proton exchanged montmorillonite clay as an efficient catalyst for the reaction of isobutylene polymerization. International Journal of Molecular Sciences. 2002; 3:790-800.

11. Harrane A, Belaouej MA, Meghabar R and Belbachir M. Cationic ring-opening polymerization of (d,1-lactide) using Maghnite-H+, a non-toxic catalyst. Reactive \& Functional Polymers. 2011; 71(2):126-130. http://dx.doi.org/10.1016/j. reactfunctpolym.2010.11.022.

12. Harrane A, Naar N and Belbachir M. Ring opening polymerization of oxetane by the use of a montmorillonite clay as catalyst. Materials Letters. 2007; 61(17):3555-3558. http://dx.doi. org/10.1016/j.matlet.2006.11.118.

13. Harrane A, Belaouedj MA, Meghabar R and Belbachir M. Bulk polycondensation of lactic acid by Maghnite-H+ a non-toxic catalyst. Journal of Polymer Research. 2012; 19(2):9785-9790.

14. Benkenfoud K, Harrane A and Belbachir M. Ring opening polymerization of tetrahydrofuran catalysed by Maghnite- $\mathrm{H}+$. Chinese Journal of Polymer Science. 2012; 30(1):56-62.

15. Haouas M, Harrane A, Belbachir M and Taulelle F. Solid State NMR Characterization of formation of Poly(epsilon-caprolactone) Maghnite nanocomposites by in situ polymerization. Journal of Polymer Science. Part B, Polymer Physics. 2007; 45(22):30603068. http://dx.doi.org/10.1002/polb.21302.

16. Draoua Z, Harrane A and Belbachir M. Amphiphilic biodegradable Poly(e-caprolactone)-Poly(ethylene glycol) - Poly(e-caprolactone) triblock copolymer synthesis by Maghnite- $\mathrm{H}^{+}$as a green catalyst. Journal of Macromolecular Science, Part A: Pure and Applied Chemistry. 2015; 52:130-137.

17. Ayat M, Harrane A and Belbachir M. Maghnite- $\mathrm{H}^{+}$a solid catalyst for the cationic Polymerization of $\alpha$-methylstyrene. Journal of Applied Polymer Science. 2008; 109(3):1476-1479. http://dx.doi.org/10.1002/app.28285.

18. Harrane A and Belbachir M. Synthesis of biodegradable polycaprolactone/ montmorillonite nanocomposites by direct insitu polymerization catalysed by exchanged clay. Macromolecular Symposia. 2007; 247(1):379-384. http://dx.doi.org/10.1002/ masy.200750144.

19. Hirosye T, Einaga $Y$ and Fujita H. Excluded-volume effects in dilute polymer solutions. VIII. Poly(d,1- $\beta$-methyl $\beta$-propiolactone) in several solvents and reanalysis of data on Poly $(\mathrm{d}-\beta-$ hydroxybutyrate). Polymer Journal. 1979; 11(10):819-826.

20. Claver C, Fernández E, Català RM, Medina F, Salagre P and Sueiras JE. Studies on the characterization of several iridium-and rhodium-clay catalysts and their activity in imine hydrogenation. Journal of Catalysis. 2001; 201(1):70-79. http:// dx.doi.org/10.1006/jcat.2001.3221.

21. Alba MD, Castro MA, Chain P, Naranjo M and Perdigon AC. Structural study of synthetic mica-montmorillonite by means of 2D MAS NMR experiments. Physics and Chemistry of Minerals. 2005; 32(4):248-254. http://dx.doi.org/10.1007/ s00269-005-0457-8.

22. Peng L, Huo H, Liu Y and Grey CP. 170 Magic angle spinning NMR studies of Brønsted acid sites in zeolites HY and HZSM-5. Journal of the American Chemical Society. 2007; 129(2):335346.

23. Omegna A, Vasic M, van Bokhoven JA, Pirngruber G and Prins R. Dealumination and realumination of microcrystalline zeolite beta: An XRD, FTIR and quantitative multinuclear (MQ) MAS NMR study. Physical Chemistry Chemical Physics. 2004; 6(2):447-452. http://dx.doi.org/10.1039/B311925D.

24. Komarneni S, Fyfe CA, Kennedy GJ and Strobl H. Solid state 27Al and 29Si magic angle spinning NMR of aluminosilicate gels. Journal of the American Ceramic Society. 1986; 69:42-44.

25. Ohkubo T, Saito K, Kanehashi K and Ikeda Y. A study on hydration behaviors of interlayer cations in montmorillonite by solid state NMR. Science and Technology of Advanced Materials. 2004; 5(5-6):693-696.

26. Okada K, Arimitsu N, Karneshima Y, Nakajima A and MacKenzie KJD. Solid acidity of 2:1 type clay minerals activated by selective leaching. Applied Clay Science. 2006; 31(3):185-193.

27. Hernandez-Laguna A, Escamilla-Roa E, Timon V, Dove MT and Sainz-Diaz C. DFT study of the cation arrangements in the octahedral and tetrahedral sheets of dioctahedral $2: 1$ phyllosilicates. Physics and Chemistry of Minerals. 2006; 33(10):655-666.

28. Stackhouse S, Coveney PV and Sandre E. Plane-wave density functional theoretic study of formation of clay-polymer nanocomposite materials by self-catalyzed in situ intercalative polymerization. Journal of the American Chemical Society. 2001; 123(47):11764-11774.

29. Greenwell HC, Jones W, Coveney PV and Stackhouse S. On the application of computer simulation techniques to anionic and cationic clays: A materials chemistry perspective. Journal of Materials Chemistry. 2006; 16:708-723. http://dx.doi. org/10.1039/b506932g.

30. Yang T, XD, Li J, Yang L. Theoretical and experimental investigations on the structures of purified clay and acid-activated clay. Applied Surface Science. 2006; 252(18):6154-6161. http:// dx.doi.org/10.1016/j.apsusc.2005.06.033.

31. Brown DR and Rhodes CN. Brønsted and Lewis acid catalysis with ion- exchanged clays. Catalysis Letters. 1997; 45(2):35-40.

32. Trombetta M, Busca G, Lenard M, Storaro L, Ganzerla R, Piovesan L, et al. Alcantara- RodriguezM, Rodriguez-Castellón E. Solid acid catalysts from clays Evaluation of surface acidity of mono- and bi-pillared smectites by FT-IR spectroscopy measurements, NH3-TPD and catalytic tests. Applied Catalysis A, General. 2000; 193(1):55-69. 